УДК 334.02

\title{
ДЕЯКІ ОСОБЛИВОСТІ І ЗАКОНОМІРНОСТІ ЕКОНОМІЧНОГО РОЗВИТКУ ІНФОРМАЦІЙНОГО СУСПІЛЬСТВА
}

\author{
Даніл ян В.О., к.ф.н., доцент, \\ Фролов O.I., к.е.н., доцент, \\ Толстов І.В., к.ф.н., доцент (УкрДУЗТ)
}

\begin{abstract}
У статті досліджено вплив розвитку інформаційно-комунікативних технологій на зміни, що відбуваються в економічній сфері життя суспільства, зокрема на формування інформачійної економіки, основу якої складають інформачійні засоби виробництва і інформаційні товари і послуги, а основним предметом $і$ засобом праці $\epsilon$ інформачія. Виявлено та проаналізовано основні особливості та закономірності економічного розвитку інформаційного суспільства.
\end{abstract}

Ключові слова: інформація, інформаційна економіка, інформаційне суспільство, інформаційно-комунікаційні технологї, інформаційні товари, «кіберекономіка».

\section{НЕКОТОРЫЕ ОСОБЕННОСТИ И ЗАКОНОМЕРНОСТИ ЭКОНОМИЧЕСКОГО РАЗВИТИЯ ИНФОРМАЦИОННОГО ОБЩЕСТВА}

\author{
Данильян В.О., к.ф.н., доцент, \\ Фролов А.И., к.э.н., доцент, \\ Толстов И.В., к.ф.н., доцент (УкрГУЖТ)
}

В статье исследовано влияние развития информационно-коммуникативных технологий на изменения, происходящие в экономической сфере жизни общества, в частности на формирование информащионной экономики, основу которой составляют информачионные средства производства и информачионные товары и услуги, а основным предметом и средством труда является информация. Выявлень и проанализированы основные особенности и закономерности экономического развития информационного общества.

Ключевые слова: информация, информационная экономика, информационное обцество, информационно-коммуникационные технологии, информационные товары, «киберэкономика».

\section{SOME PECULIARITIES AND REGULARITIES OF ECONOMIC DEVELOPMENT OF INFORMATION SOCIETY \\ Danilian V.O., Ph.D., associate professor, \\ Frolov A.I., Ph.D., associate professor, Tolstov I.V., Ph.D., associate professor, (USURT)}

The modern type of society over the past decades is increasingly characterized as an information society. As is known, information technologies are the direct engine of the globalization process, which is connected with the new technical possibilities of communication, and the most important feature is the formation of a single financial and

(C) Даніл'ян B.O.,

Фролов О.I.,

Вісник економіки транспорту і промисловості № 62, 2018

Толстов І.В. 
information space in the world, in which the commercial activities of mankind are increasingly carried out.

The article analyzes the influence of the development of information and communication technologies on the changes taking place in the economic sphere of society's life. The main features and regularities of the economic development of the information society were identified and analyzed. The latest large-scale economic changes taking place in the world are characterized by the emergence of an "information economy". While industrial technologies dominated the capitalist system as a social system, in today's globalizes world, information and communication technologies based on the exchange of knowledge and information are of unquestionable priority. The development of information and communication technologies contributes to changes in the field of economic relations, in particular the formation of an information economy, the basis of which are information media and information products and services. The main subject and means of work in the information economy are information, the main product of production and consumption services and information products. The combination of industrial and post-industrial types of development, the use of information and knowledge as a unique object and means of production, the growth of the service sector, especially the manifestation of the labor theory of value, technological and economic convergence, innovative type of development, the dynamism of production, virtualization of the economic space - the most important economic basis of the information society.

Key words: information, information economy, information society, information and communication technologies, information products, "kiber economy".

Постановка проблеми. Сучасний
тип суспільства протягом останніх
десятиліть усе частіше характеризують як
інформаційне суспільство.

Як відомо, інформаційні технології

є безпосереднім двигуном процесу глобалізації, яка пов'язана 3 новими технічними можливостями комунікації, та найважливішою особливістю якої $\epsilon$ формування єдиного в масштабах усього світу фінансово-інформаційного простору, в якому все більшою мірою здійснюється комерційна діяльність людства. Саме розвиток сучасних інформаційних i комунікаційних технологій, зростання обсягу інформації все більше визначають сутність нашої епохи. Новітні інформаційно-комунікаційні технології здійснюють величезний перетворювальний вплив на всі сфери сучасного суспільства як у межах національних кордонів, так i у світі в цілому. Глобальність процесів, що відбуваються, неминуче підвищує інтерес до теоретичного осмислення особливостей інформаційного

суспільства емпіричного вивчення впливу інформаційно-комунікаційних технологій на трансформацію соціально-економічних, політичних і культурних структур.

Аналіз публікацій. Значний внесок у дослідження проблеми становлення та розвитку інформаційної економіки зробили вітчизняні та зарубіжні вчені, зокрема Д. Белл [1], В.М. Геец [2], М. Кастельс [6], Л.Г. Мельник [7, 8], Е. Тоффлер [14] та ін. Зокрема, наявні наукові праці присвячені дослідженню економічних аспектів інформаційної економіки, успішному зарубіжному досвіду іiі розвитку. Актуальність наукових досліджень проблем функціонування та розвитку інформаційної економіки пояснюється недостатньою теоретичною розробкою їх в науковій літературі.

В зв язку з цим метою статті $\epsilon$ виявлення та аналіз деяких особливостей i закономірностей економічного розвитку інформаційного суспільства.

Викладення основного матеріалу дослідження. Вчені по-різному називають 
сучасний

суспільний

постекономічне,

постіндустріальне,

інформаційне суспільство чи суспільство знань.

Однак, як би не називався цей етап розвитку суспільства, практично всі дослідники вважають основним фактором, що визначає розвиток сучасної економіки, ii інформатизацію. Провідну роль у новому суспільстві відіграє інформація - і як базовий фактор продуктивного процесу, i як ключовий компонент процесів, що відбуваються в суспільстві. Розвиток світових інформаційних ресурсів грає все зростаючу роль в досягненні динамічного розвитку економіки і підвищенні якості життя населення. Існуюча сьогодні інформаційна культура суспільства проявляється в його здатності формувати інформаційні ресурси, сучасні засоби інформатики i інформаційні технології на користь забезпечення своїх життєдіяльності і розвитку.

Класики постіндустріалізму цілком адекватно визначили роль інформації, знань і технологій у сучасному суспільстві та переконливо довели, що інформаційний сектор економіки матиме тенденцію до глобалізації і зростання. Так, М. Кастельс пише, що в останні два десятиліття у світі створена економіка нового типу, яку він називає інформаціональною і глобальною. "Інформаціональна оскільки продуктивність і конкурентоспроможність факторів чи агентів у цій економіці (буде то фірма, регіон чи нація) залежать у першу чергу від їхньої здатності генерувати, обробляти й ефективно використовувати інформацію, основану на знаннях. Глобальна - оскільки основні види економічної діяльності, такі як виробництво, споживання та циркуляція товарів і послуг, а також їх складові (капітал, праця, сировина, управління, інформація, технологія, ринки), організуються в глобальному масштабі безпосередньо або 3 використанням розгалуженої мережі, що пов'язує економічних агентів. I нарешті, інформаціональна і глобальна - оскільки в нових історичних умовах досягнення певного рівня продуктивності й існування конкуренції можливе лише всередині глобальної взаємозалежної мережі» [6, c.68].

Філософське значення цього фактора, як уявляється, полягає в тому, що людська діяльність здебільшого базується на знаннях та інформації, кодифікованих у різних інформаційних технологіях. "Інтелектуалізація" і глобалізація економічного життя потребують відповідних змін у соціальній організації суспільства, у сфері освіти, у способах виробництва. Знання, зафіксовані в технологіях і глобалізаційних комп'ютерних системах, стають об'єктивним фактором економічного розвитку.

Звичайно, інформацію накопичували та цінували завжди. Новим виявляється стрімке зростання економічного значення інформаційних ресурсів, що спостерігається за останні десятиліття в промислово розвинених країнах. В інформаційному суспільстві виробничий базис складають інформаційні засоби виробництва, основним продуктом споживання (отже, i виробництва) $\epsilon$ інформаційні товари та послуги, а ключовим фактором структуризації суспільства $\epsilon$ інформація [13, с. 71]. Інформація i знання, що розуміються не як субстанція, втілена у виробничих процесах чи засобах виробництва, а вже як безпосередня виробнича сила, стають найважливішим фактором сучасного господарства, базовим фактором суспільного виробництва. Д. Белл пише: “Якщо індустріальне суспільство основане на машинній технології, то постіндустріальне суспільство формується під впливом технології інтелектуальної. I якщо капітал та праця - головні структурні елементи індустріального соціуму, то інформація i знання - основа суспільства постіндустріального" [1, с. CLI]. 
Можна погодитися 3 поширеним у зарубіжній літературі поняттям

\section{“інформаційна}

економіка",

що характеризує сучасну тенденцію розвитку світової економіки, пов'язану зі зростанням ролі інформаційної індустрії і знань в економічному житті суспільства. "Під інформаційною економікою, відзначає український дослідник Л.Г. Мельник, -- очевидно, слід розуміти виробничу систему в поєднанні зі сферою споживання, де інформація є провідною продуктивною силою (вирішальним засобом i предметом праці), а також основним продуктом виробництва та предметом споживання" [7, с. 86]. Це економіка, у якій домінуючим фактором $\epsilon$ процеси накопичення та використання знань; у якій спеціалізовані (наукові) знання, як i повсякденні, стають найважливішим ресурсом, який, поряд із працею, капіталом i природними ресурсами, забезпечує зростання та конкурентоспроможність економічної системи. В інформаційній економіці визначальним $\epsilon$ інтелектуальний потенціал суспільства, що існує у свідомості людей і матеріалізується в технологічних способах виробництва [2, с. 17].

Нині у розвинених країнах формується постматеріальна економіка, де найважливішим активом виявляються не матеріально відчутні ресурси - товари, сировина, робоча сила, устаткування, а щось невловиме - інтелект, інформація, знання.

У постіндустріальному світі “люди працюють мозком замість рук, ... комунікаційні технології створюють глобальну конкуренцію, ... нововведення важливіші за масове виробництво, ... інвестиції вкладаються радше в нові концепції чи засоби їхнього створення, ніж нові машини, ... і постійними є лише швидкі зміни" [12, с. 50].

Цілком об'єктивним є виникнення передумов, у яких формується інформаційна економіка. Однією 3 таких передумов $\epsilon$ вичерпання соціальноекономічних форм розвитку суспільства в рамках існуючих природно-ресурсних i екологічних умов [13]. Дослідники відзначають: саме природно-ресурсні кризи були основними винуватцями та першопричинами будь-яких малих i великих соціально-економічних революцій, що відбуваються в різних куточках земної кулі. За словами $\mathrm{H}$. Реймерса, “завжди спостерігалася відповідність між розвитком продуктивних сил і природно-ресурсним потенціалом суспільного прогресу” [11, с. 164].

Загій Зальні особливості ситуації, у якй можуть проявитися контури інформаційного суспільства, яскраво відбиті К. Боулдингом в образі “економіки космонавтів"; у ній, подібно до космічного корабля, всі джерела і ресурси мають певні обмеження 3 точки зору припливу та відтоку. Тому людина має створити циклічну економічну систему, що має здатність нескінченно відтворювати різні матеріальні форми. Однак інформація - це єдина природна субстанція, добування якої із середовища не завдає безпосередніх збитків природі. Крім того, на відміну від виробничого споживання матеріалів чи енергії, що веде до збільшення ентропії, використання інформації дає протилежний ефект: підвищує організованість, упорядкованість навколишнього середовища [3, с. 81].

Якщо земля, капітал і праця мають, хоча й різною мірою, обмежений характер, то інформація і знання безмежні. Людству доводиться освоювати принципово нову систему трудової діяльності, у якій основу продуктивних сил (засобів виробництва, предметів i продуктів праці) складають не звичні відчутні матеріальні об'єкти, а незримі й невідчутні інформаційні фантоми. Зовнішню оболонку у вигляді матеріальних носіїв вони мають лише через природу фізичних обмежень, що 
потребують збереження в пам'яті інформаційних образів та практичного сприйняття їх матеріальною сутністю людини.

Інформація не має властивості матеріального світу. Вона непідвладна просторово-часовим обмеженням, оскільки сама формує ці обмеження. "На відміну від матеріальних товарів, інформаційні продукти не споживаються, а використовуються - адже їх не можна "спожити" (в розумінні використати без залишку). Скільки їх не використовуй, менше не стає. Вони не зникають i фізично не зношуються“, - відзначає Л.Г. Мельник [7, с. 83-84].

Таким

чином,

можна сформулювати такі основні властивості інформаційних товарів: можливість тиражування безліч разів у нескінченно малому обсязі простору за нескінченно малі інтервали часу; фізична незношуваність; відсутність фізичних перешкод безоплатного привласнення інформаційних товарів і засобів виробництва будь-ким; для одержання благ основним стає не фізичне володіння засобами виробництва, а інтелектуальна спроможність їхнього використання (освоєння) [7;8].

Крім того, інформація не має властивості рідкості. Споживання інформації тотожне формуванню нового знання. “Знання розширюються i саморегулюються, вони нарощуються в міру використання. Таким чином, в економіці знань рідкість ресурсів замінена на їхню поширеність" [4, с. 342]. У цьому контексті очевидно: поширення інформації тотожне іiі самозростанню, що виключає застосування до цього феномену поняття рідкості. До інформації не може бути застосована така характеристика, як споживання в традиційному розумінні цього терміна. Використання інформації сприяє виникненню нової інформації i нового знання, не перешкоджаючи іншим членам суспільства застосовувати іiі для власних цілей [5].
Виходячи 3 цього, дослідники дійшли висновку, що інформація має характеристики суспільного блага, якщо, за Ф. Махлупом, розуміти під ним щось таке, чим додатково може скористатися людина, не збільшуючи витрат виробництва. Останнє прямо припускає, що 3 технічної чи концептуальної точок зору ніщо не може вимірити вартість таких благ у ринкових термінах. Таким чином, сама поширеність і певного роду нелімітованість інформації зумовлюють неможливість вартісної оцінки як іiі самої, так і продуктів, у створенні яких вона відіграє домінуючу роль.

Ці принципово нові властивості засобів виробництва та товарів не можуть не руйнувати традиційних виробничих відносин, основою яких століттями залишалася матеріальність компонентів економічної системи і зумовлені нею фізичні й економічні закономірності та принципи. Закладені в основу інформаційної економіки компоненти виробничої системи мають зовсім іншу природу реалізації. Це потребує докорінного перегляду ключових принципів організації громадського життя. У процесі інформатизації суспільства значних змін зазнають відносини власності на інформаційні засоби виробництва, товарно-грошові відносини, інші атрибути економіки.

Так, процеси, що привели до істотних перетворень у системі продуктивних сил сучасного світового господарства, надали інформації значення вирішального засобу праці, одночасно висунувши іiі й у ряд провідних предметів праці, що підлягають перетворенню, обробці, збереженню, передачі, споживанню в процесі матеріального i духовного виробництва.

У найбільш розвинених країнах, галузі, що виробляють знання та інформаційні продукти, в даний час стають первинним сектором економіки. У зв'язку 3 цим заслуговує на увагу думка деяких авторів: виділення і відносне 
відокремлення нової сфери діяльності виробництва інформації - слід розглядати як четвертий великий етап суспільного поділу праці (після виокремлення землеробства, скотарства, ремісництва, торгівлі) [14, с. 11].

$$
\text { Формування }
$$

інформаційної

індустрії зумовлено певними обставинами: інформація все більше стає продуктивною силою; заміна ручної праці розумовою означає водночас інформатизацію економіки; глобалізація громадського життя збільшує роль комунікаційних засобів (прикладом $\epsilon$ Інтернет); інформатизація економіки означає постійне підвищення ефективності виробництва й удосконалювання його екологічного рівня; посилення позицій людини в тріаді “біотрудо-соціо" приводить до збільшення потреби в інформаційних товарах і послугах [7].

Загалом інформаційну індустрію можна визначити як галузь економіки, пов'язану 3 виробництвом, обробкою, передачею, збереженням усіх видів інформації, створенням необхідних для цього технологічних пристроїв (виділяються три галузі інформаційної індустрії: виробництво інформаційного й комунікаційного устаткування, зв'язок і виробництво змісту (інформації)). Вона $\epsilon$ найдинамічнішим сектором світової економіки, породжує продукти і послуги, що істотно змінюють характер ведення бізнесу в традиційних галузях, безпосередньо не пов'язаних зі створенням, переробкою та поширенням інформації. Використання інформаційнокомунікаційних технологій у багатьох сферах послуг i промисловості стало вкрай необхідним елементом конкурентної боротьби й економічного розвитку [9].

Роль і значення інформаційної індустрії у світовій економіці стають усе значнішими. Західноєвропейський ринок інформаційних i комунікаційних технологій має вищі темпи зростання
$(7,2 \%)$, ніж економіка в цілому[3, с. 84]. У більшості розвинених країн питома вага інформаційної індустрії у ВВП знаходиться на рівні 5\%, в Великобританії, Угорщини, Ірландії, Республіці Корея, США, Японії цей показник досягає 7\% [15].

Однією 3 особливостей інформаційної економіки $є$ поєднання індустріального та постіндустріального типів розвитку. Використання знань i інформації як основних виробничих ресурсів значуще нині саме тому, що воно проникає в усі сфери економіки, а не концентрується лише в іï окремих секторах. У результаті основаною на знанні виявляється практично вся сучасна економічна система.

Новітні інформаційні технології стають знаковим фактором модернізації традиційної економіки, методів керування в комерційних організаціях і структурах державної влади - відбувається конвергенція “нової” та традиційної “старої” економік. Доказом слугує той факт, що нині 85\% інвестицій у технології “нової економіки" здійснюються компаніями традиційної економіки i спрямовані вони на розвиток інформаційно-технологічної бази корпорацій [10].

\section{Розглядаючи}

особливості економічних основ інформаційного суспільства відзначимо, що ключовою зміною парадигми при переході до інформаційної економіки може бути зрушення від технології, основаної, головним чином, на використанні дешевої енергії, до технології, основаної на дешевих вкладеннях інформації, почерпнутих 3 індустрії переробки інформації. Інформація стає головною виробничою сировиною.

Так, М. Кастельс пише: "При індустріальному способі розвитку головне джерело продуктивності - у введенні нових енергетичних джерел та в здатності децентралізувати використання енергії в процесах виробництва i розподілу. У 
новому, інформаціональному способі розвитку джерело продуктивності полягає в технології генерування знань, обробки інформації та символічної комунікації. Зрозуміло, знання й інформація $\epsilon$ критично важливими елементами в усіх способах розвитку, оскільки процес виробництва завжди оснований на деякому рівні знань і обробці інформації. Однак специфічним для інформаціонального способу розвитку $\epsilon$ дія знання на саме знання як головне джерело продуктивності““ [6, с. 38-39].

Зростання галузей сфери послуг $\epsilon$ найважливішою особливістю інформаційної економіки. Значення сфери послуг постійно зростає і iї частка в економічно розвинених країнах уже нині складає $40-60 \%$ і очікується - в найближчому майбутньому вона збільшиться ще на 10-15\%. Якщо раніше панувало матеріальне виробництво, то нині панівною стала сфера послуг, тобто нематеріальне виробництво. Це зовсім не означає, що матеріальне виробництво зникло. Воно продовжує існувати, але завдяки високому науково-технічному рівню виробництва і продуктивності праці функціонування такого могутнього промислового потенціалу, як, наприклад, американський, забезпечують усього лише $10 \%$ зайнятих [3, с. 87].

Домінування сфери послуг означає, що найпоширенішим продуктом праці $\epsilon$ послуги, що створюються, зазвичай, інтелектуальною, а часто творчою працею, витрати якої визначити надзвичайно складно, що призводить до підриву ринкових відносин, насамперед їхнього основного закону - закону вартості, еквівалентних відносин. У цьому контексті Д. Белл формулює проблему інформаційної теорії вартості. "Коли знання у своїй систематичній формі втягується в практичну переробку ресурсів (у вигляді винаходу чи організаційного вдосконалення), можна сказати, що саме знання, а не праця $є$ джерелом вартості”, - пише він. I пояснює:
“Промислові товари виробляються у вигляді відособлених, розпізнаваних одиниць, що обмінюються та продаються, споживаються і використовуються... Інформація та знання не споживаються i не "витрачаються". Знання - суспільний продукт, і його витрати, ціна й вартість дуже відрізняються від відповідних показників промислових товарів... Знання являє собою “колективне благо”, оскільки за своїм характером з моменту створення воно стає доступним усім..." [1, с. CLI].

3 точки зору трудової теорії вартості істотними стають два факти. 3 одного боку, витрати виробництва інформації і знання стають незлічимими, оскільки діяльність 3 їх створення вже не можна розглядати як один із видів традиційної праці. 3 іншого боку, процес тиражування інформації не $\epsilon$ «відтворювальним» процесом у власному розумінні слова, отже, витрати праці на відтворення блага, що $є$ об'єктивною стороною вартісного відношення, стають в умовах інформаційної економіки вкрай ірраціональним поняттям, не здатним одержати кількісну оцінку [5].

Ще однією важливою особливістю інформаційної економіки $є$ зростаюча технологічна й економічна конвергенція. Конвергенцію можна охарактеризувати як процес об'єднання різних технологій, ринків, форм регулювання різних галузей інформаційної індустрії. У цьому разі відбувається розмивання меж між секторами інформаційної індустрії, такими як виробництво комунікаційного устаткування, комп'ютерів, надання комунікаційних мережевих послуг, розробка програмного забезпечення, мультимедійні розподільні мережі, виробництво мультимедійного й аудіовізуального змісту. Відбувається конвергенція різних засобів передачі інформації, таких як провідна, безпровідна й ефірна технології, аналоговий i цифровий зв'язок та ін. [9].

Технологічна спільність створює умови для організаційної, корпоративної 
єдності, тобто злиття компаній інформаційної індустрії, як таких, що представляють різні іï сектори. Їх мета об'єднати фінансову та технологічну міць, запропонувати споживачеві нові послуги, усунути конкурентів, одержати доступ до нових ринків.

Крім того, інформаційна економіка характеризується інноваційним типом розвитку та швидкою динамікою виробництва. Причина цього явища зростаючі темпи виникнення інновацій, тобто факторів (процесів, технологій, принципів, продуктів), що оновлюють виробництво.

Слід відзначити, що інформаційній економіці властиве значне зниження питомих витрат виробництва. На думку Д. Белла, знання зменшує вартість завдяки заощадженню капіталу: заміна працівників машинами сприяє економії праці, зберігаються інвестиції, адже "кожна наступна одиниця капіталу ефективніша та продуктивніша, ніж попередня, i, отже, на одиницю продукції потрібно менше витрат" [1, с. 58 -59].

Наступною

характеристикою

наочною економіки $є$ віртуалізація економічного простору, чи «кіберекономіка». Передумовою цього феномену стало створення комп'ютерних мереж та інтернетизація економіки. Під "кіберекономікою" можна розуміти економічну активність, спрямовану на створення інформаційних продуктів i послуг в Інтернеті та глобальних комерційних мережах, а саме: електронної торгівлі, маркетингу, реклами, публікацій, інвестицій, поширення аудіовізуальної продукції й ін. [9].

Діловий інтерес до Інтернету викликаний декількома факторами: створенням легкого в користуванні програмного забезпечення для пошуку потрібних відомостей у колосальних інформаційних ресурсах, низькою вартістю глобальних комунікацій i численними потенційними споживачами.
У віртуальному просторі практично одночасно доступна вся світова торгівля, й споживач ненав'язливо затягується у віртуальний маркет, де провокується на покупку. Крім того, світова економіка починає розглядати електронну комерцію як один із провідних напрямів свого розвитку з таких причин:

- Інтернет уже повсюдно став нормою ділового життя, всесвітній кіберпростір дозволяє надавати послуги on-line i здійснювати віртуальні моделі, неможливі за інших умов;

- утрачають значення фактори простору та часу, комерційна діяльність поширюється на весь світ без великих витрат;

- зменшуються трансакційні витрати завдяки прямому контакту споживача з виробником в інтерактивному режимі без посередників;

- виникає можливість формувати в масштабі реального часу будь-які доступні конфігурації виробів за бажанням споживача;

- умови взаємодії для всіх однакові: невеликі компанії часто можуть на рівних конкурувати з великими і добре відомими;

- мас-медіа електронного ринку сприятливий простір реклами - дозволяє здійснювати мережевий інтерактивний маркетинг [10].

Висновки. Таким чином, новітні масштабні економічні зміни, які відбуваються у світі, характеризуються становленням “інформаційної економіки”. Якщо в капіталістичній системі як суспільному ладі домінували індустріальні технології, то в сучасному світі, що глобалізується, безумовний пріоритет мають інформаційно-комунікаційні технології, основані на обміні знаннями й інформацією. Розвиток інформаційнокомунікаційних технологій сприяє змінам у сфері економічних відносин, зокрема формуванню інформаційної економіки, основу якої складають інформаційні засоби виробництва й інформаційні 
товари та послуги. Основним предметом і засобом праці в інформаційній економіці $\epsilon$ інформація, головним продуктом виробництва та споживання - послуги й інформаційні товари. Поєднання індустріального і постіндустріального типів розвитку, використання інформації та знань як унікального предмета і засобу виробництва, зростання сектора послуг, особливості прояву трудової теорії вартості, технологічна й економічна конвергенція, інноваційний тип розвитку, динамічність виробництва, віртуалізація економічного простору - найважливіші економічні підстави інформаційного суспільства.

\section{СПИСОК ВИКОРИСТАНИХ ДЖЕРЕЛ}

\section{1. Белл}

постиндустриальное

Д.

Грядущее социального прогнозирования / Д. Белл; пер. с англ. - М.: Acadeмia, 1999. - 956 с.
2. Геец
B.M.
Социально-

экономические трансформации при переходе к экономике знаний / В.М. Геец // Социально-экономические проблемы информационного общества / под ред. д. э. н., проф. Л.Г. Мельника. - Сумы: ИТД «Университетская книга», 2005. - С. 16-33.

3. Даніл'ян В.О. Інформаційне суспільство та перспективи його розвитку в Україні (соціально-філософський аналіз). Монографія. - Харьков: Право, 2008. - 184 c.

4. Делягин М. Мировой кризис: Общая теория глобализации / М. Делягин. - М.: ИНФРА-М, 2003. - 767 c.

\section{5. Иноземцев}

Постиндустриальное общество как теоретическая конструкция формирующаяся реальность / В.Л. Иноземцев // Социально-экономические проблемы информационного общества / под ред. д.э.н., проф. Л.Г. Мельника. Сумы: ИТД «Университетская книга», 2005. - С. 120-148.
6. Кастельс М. Информационная эпоха: общество и культура / М. Кастельс; пер. с англ. ; под ред. О.И. Шкаратана. М.: ГУ ВШЭ, 2000. - 608 c.

7. Мельник Л.Г. Информационная экономика: монография / Л.Г. Мельник. Сумы: ИТД «Университетская книга», 2003. - 288 c.

8. Мельник Л.Г. Предпосылки формирования информационного общества / Л.Г. Мельник // Социальноэкономические проблемы информационного общества / под ред. д.э.н., проф. Л.Г. Мельника. - Сумы: ИТД «Университетская книга», 2005. - С. 60-87.

9. Мелюхин И.С. Информационное общество: истоки, проблемы, тенденции развития / И.С. Мелюхин. - М.: МГУ, 1999. - 208 с.

10. Мясникова Л. «Новая экономика» в пространстве постмодерна / Л. Мясникова // Мировая экономика и международные отношения. - 2001. - № 12. - С. 3-15.

11. Реймерс Н.Ф. Экология (теории, законы, правила, принципы и гипотезы) / Н.Ф. Реймерс. - М.: Россия молодая, 1994. $367 \mathrm{c}$.

12. Семиноженко В.П. Инновационное развитие как безальтернативный путь планирования будущего / В.П. Семиноженко // Социальноэкономические проблемы информационного общества / под ред. д.э.н., проф. Л.Г. Мельника. - Сумы: ИТД «Университетская книга», 2005. - С. 49-58.

13. Социально-экономические проблемы информационного общества / под ред. д.э.н., проф. Л.Г. Мельника. - Сумы: ИТД «Университетская книга», 2005. - 430 с.

14. Тоффлер Э. Третья волна / Э. Тоффлер; пер. с англ. - М.: ООО «Издательство АСТ», 2004. - 781 с.

15. Цифровая экономика [Электронный ресурс]. - Режим доступа: https://issek.hse.ru/data/2017/09/28/1159186870 /DE_2_28.09.17.pdf 